\title{
The Effect of Mechanical Alloying on the Microhardness and Fracture Toughness of $\mathrm{BaTiO}_{3}$
}

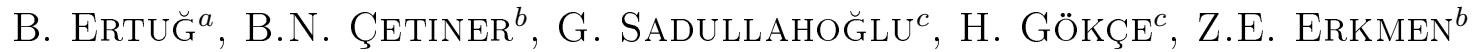 \\ AND M.L. ÖVEÇOĞLU ${ }^{c}$ \\ ${ }^{a}$ Orion Company Industry and Trade Ltd., Organized Industrial Zone, Metal İş Sanayi Sitesi 5. \\ Blok No:2, Ikitelli, Istanbul, Turkey \\ ${ }^{b}$ Marmara University, Metallurgical and Materials Eng., 34722 Göztepe, Istanbul, Turkey \\ ${ }^{c}$ Istanbul Technical University, Metallurgical and Materials Eng, 34469 Maslak, Istanbul, Turkey
}

\begin{abstract}
In this work, the effects of mechanical alloying on the mechanical properties of $\mathrm{BaTiO}_{3}$ were investigated. In order to examine the milling conditions and sintering parameters on the solid state formation of $\mathrm{BaTiO}_{3}, \mathrm{X}-\mathrm{ray}$ diffraction technique was used. After mechanical alloying process, nanosized powder mixtures were produced. Sintering temperatures were $600,700,800,900,1000$, and $1200^{\circ} \mathrm{C}$ and sintering duration was $1 \mathrm{~h}$. Besides X-ray diffraction examinations, mechanical properties of the $\mathrm{BaTiO}_{3}$ samples were determined by Vickers microhardness test.
\end{abstract}

DOI: 10.12693/APhysPolA.123.188

PACS: 81.07.Bc, 62.25. $-\mathrm{g}, 81.20 . \mathrm{Ev}, 62.20 . \mathrm{mm}$

\section{Introduction}

The classical ways of preparing titanate (BT) powders involve the reaction between carbonates, oxides, or hydroxides of the constituent elements at high temperatures [1]. $\mathrm{BaTiO}_{3}$ can be prepared by conventional calcination method, in which a certain amount of $\mathrm{BaCO}_{3}$ or $\mathrm{BaO}$, and $\mathrm{TiO}_{2}$ are calcined and then pulverized. However, $\mathrm{BaTiO}_{3}$ powders prepared by this method consist of non-uniform and coarse particles [2]. Thus mechanical milling prior to sintering is a necessary step for the solid state production of barium titanate.

Mechanical milling studies related to barium titanate included changing milling time or milling speed (low milling speed and comparable milling time) [3]. Chaisan et al. [4] combined comparable milling time (i.e. $30 \mathrm{~h}$ ) and sintering temperature $\left(1200^{\circ} \mathrm{C}\right)$ in order to produce nano $\mathrm{BaTiO}_{3}$. Petrovic et al. [5] used milling to de-agglomerate the powders prepared by chemical process. A combined effect of wet or dry milling with sintering at $1000{ }^{\circ} \mathrm{C}$ was used to produce nano $\mathrm{BaTiO}_{3}$ by Sundararajan et al. [6]. Singh and Nath [7] used low speed milling with comparable milling time $(1 \mathrm{~h}$ and $30 \mathrm{~h})$ and finally produced nano $\mathrm{BaTiO}_{3}$. In mechanochemical synthesis of barium titanate, a milling time of $4 \mathrm{~h}$ was employed with a sintering temperature of $1330{ }^{\circ} \mathrm{C}$ to produce barium titanate with good crystallinity [8]. Mechanical activation was employed to maintain early decomposition of barium carbonate and form barium titanate by Brzozowski and Castro [9]. Barium titanate nanoparticles was synthesized with using only mechanochemical route by Ohara et al. [10]. In this study, the effect of long milling on the phase composition and mechanical properties of barium titanate was investigated.

\section{Experimental procedure}

$\mathrm{BaTiO}_{3}$ samples were prepared by using the raw materials of $\mathrm{BaCO}_{3}$ and $\mathrm{TiO}_{2}$ (>99\%, Merck KGaA, Germany) with a molar ratio of 1.00 . The mixture of starting powders was dry milled for $24 \mathrm{~h}$ in a stainless steel vial using Spex (marka model). The powders were then pressed into pellets. The green compacts were heated at $600{ }^{\circ} \mathrm{C} / 1 \mathrm{~h}+800{ }^{\circ} \mathrm{C} / 1 \mathrm{~h}, 700^{\circ} \mathrm{C} / 1 \mathrm{~h}+900{ }^{\circ} \mathrm{C} / 1 \mathrm{~h}$, $800^{\circ} \mathrm{C} / 1 \mathrm{~h}+1000^{\circ} \mathrm{C} / 1 \mathrm{~h}, 900^{\circ} \mathrm{C} / 1 \mathrm{~h}+1100^{\circ} \mathrm{C} / 1 \mathrm{~h}$, $1000^{\circ} \mathrm{C} / 1 \mathrm{~h}+1200^{\circ} \mathrm{C} / 1 \mathrm{~h}$ and at $1200^{\circ} \mathrm{C} / 1 \mathrm{~h}$ in air and then furnace cooled. The porosity of the ceramics was measured using the Archimedes method. Vickers microhardness (100 g and $25 \mathrm{~g}$ ) and fracture toughness (200 g) of the samples were measured using Schimadzu tester.

\section{Results and discussion}

Figure 1 and Table indicates SEM image of the starting powder mixture after dry milling for $24 \mathrm{~h}$. Energy dispersive spectroscopy (EDS) analysis taken from several points of the powder microstructure showed that each particle contains equal amounts of the constituents.

Percentage of elements.

TABLE

\begin{tabular}{c|c|c|c|c|c}
\hline \hline Element & $\mathrm{C}$ & $\mathrm{O}$ & $\mathrm{Ti}$ & $\mathrm{Ba}$ & Total \\
\hline$[\%]$ & 5.73 & 25.25 & 17.83 & 51.20 & 100.0
\end{tabular}

After long milling, $\mathrm{BaCO}_{3}$ and $\mathrm{TiO}_{2}$ were homogeneously dispersed in each other. In Fig. 1, EDS analysis from point $X$ confirmed these results.

As-sintered densities of the samples increased with sintering temperature. Both two-step and one-step sintering yielded high densities as shown in Fig. 2. There is an important rise in the density when the sample was sintered 


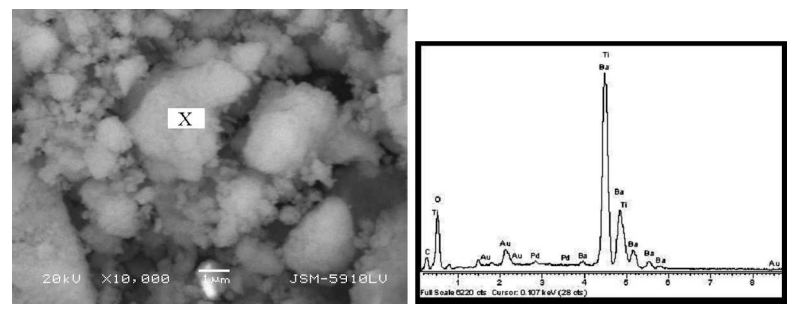

Fig. 1. SEM micrograph of milled $\mathrm{BaCO}_{3}$ and $\mathrm{TiO}_{2}$ powder mixture for a duration of $24 \mathrm{~h}$ and EDS analysis of the point on the bright region.

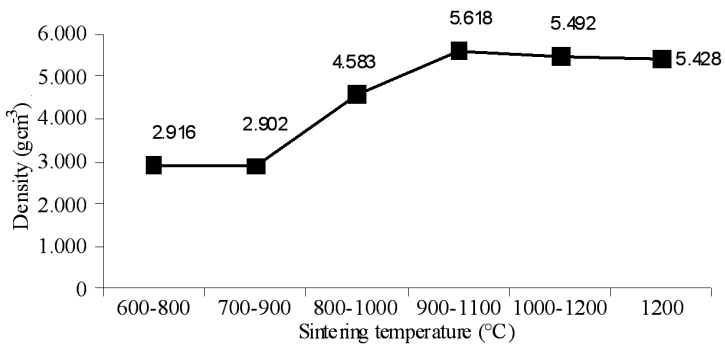

Fig. 2. As-sintered densities of the barium titanate samples.

at $1000^{\circ} \mathrm{C} / 1 \mathrm{~h}+1200^{\circ} \mathrm{C} / 1 \mathrm{~h}$ and at $1200^{\circ} \mathrm{C} / 1 \mathrm{~h}$. The maximum density was reached after two-step sintering and it was $5.618 \mathrm{~g} / \mathrm{cm}^{-3}$.

After sintering at lower temperatures, i.e. $600^{\circ} \mathrm{C}$, a high porosity was present. The porosities were $51.6 \%$ and $51.8 \%$ after sintering at $600{ }^{\circ} \mathrm{C}$ and $700^{\circ} \mathrm{C}$, respectively. In a study dealing with $\mathrm{Al}_{2} \mathrm{O}_{3}$ addition to barium titanate, $95 \%$ of theoretical density was achieved for pure barium titanate. In the study of Panteny et al. [11] the sintering of the pure barium titanate starting powder produced samples with a final density of $94.5 \%$, a typical value. In the study of Namsar et al. [12] a relative density of $77.8 \%$ was found for pure barium titanate, which is low in comparison to other literature values.

The Vickers microhardness results were in good agreement with as-sintered densities. The Vickers microhardness values increased with sintering temperature.

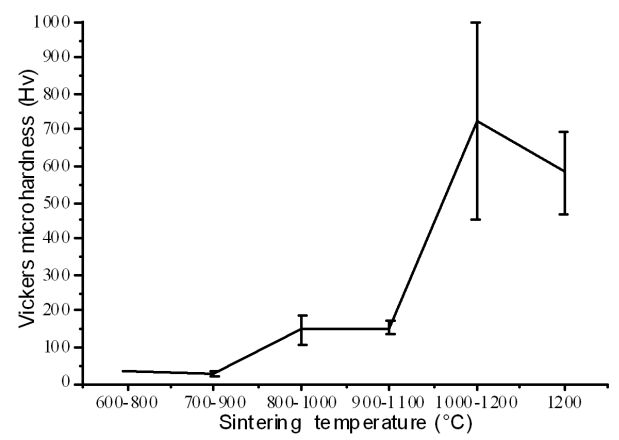

Fig. 3. Vickers hardness of barium titanate samples.
A drastic rise in the Vickers microhardness was observed as shown in Fig. 3 when the samples were sintered at $1000^{\circ} \mathrm{C} / 1 \mathrm{~h}+1200^{\circ} \mathrm{C} / 1 \mathrm{~h}$ and at $1200^{\circ} \mathrm{C} / 1 \mathrm{~h}$. However, two-step sintering $\left(1000 \mathrm{C} / 1 \mathrm{~h}+1200^{\circ} \mathrm{C} / 1 \mathrm{~h}\right)$ resulted in higher microhardness value, which was $724.2 \mathrm{Hv}$ $(7.1 \mathrm{GPa})$. A direct sintering at $1200^{\circ} \mathrm{C} / 1 \mathrm{~h}$ yielded $583.8 \mathrm{Hv}(5.73 \mathrm{GPa})$. Jiansirisomboon et al. [13] measured microhardness as $3.63 \mathrm{GPa}$ for pure barium titanate after sintering at $1300^{\circ} \mathrm{C}$ for $2 \mathrm{~h}$. The microhardness of barium titanate based dielectric ceramics were measured to be $11.3 \pm 1 \mathrm{GPa}, 11.3 \pm 0.9 \mathrm{GPa}$ and $11.9 \pm 0.6 \mathrm{GPa}$ for 3 different company products. In the study of Panteny et al. [11], the hardness of monolithic barium titanate was determined to be $4 \mathrm{GPa}$. Cook et al. [14] found the Vickers microhardness value of $5.9 \mathrm{GPa}$, lower than our study for cubic and tetragonal barium titanate. $1.38 \pm 0.07 \mathrm{GPa}$ was the result of Namsar et al. [12] for pure barium titanate, quite lower than that found in our study.

Wereszczak et al. [15] measured the fracture toughness of 3 different dielectric ceramics as $1.36 \pm 0.29,1.11 \pm 0.26$ and $1.53 \pm 0.47 \mathrm{MPa} \mathrm{m}{ }^{1 / 2}$. In the study of Panteny et al. [11], monolithic barium titanate gave the fracture toughness value of $2 \mathrm{MPa} \mathrm{m} \mathrm{m}^{1 / 2}$. Cook et al. [14] determined the fracture toughness of cubic and tetragonal barium titanate as 0.95 and $0.79 \mathrm{MPa} \mathrm{m} \mathrm{m}^{1 / 2}$, respectively. Namsar et al. [12] found a fracture toughness value close to that found in our study, i.e. $0.45 \pm$ $0.03 \mathrm{MPa} \mathrm{m} \mathrm{m}^{1 / 2}$. In our study, we found the fracture toughness as $0.56 \mathrm{MPa} \mathrm{m} \mathrm{m}^{1 / 2}$ and $0.623 \mathrm{MPa} \mathrm{m}^{1 / 2}$ for $1200{ }^{\circ} \mathrm{C}$ and $1000^{\circ} \mathrm{C}$ plus $1200^{\circ} \mathrm{C}$, respectively.

\section{Conclusion}

After long milling, i.e. $24 \mathrm{~h}, \mathrm{BaCO}_{3}$ and $\mathrm{TiO}_{2}$ were homogeneously dispersed in each other as confirmed by EDS analysis. The maximum density was reached after two-step sintering and it was $5.618 \mathrm{~g} / \mathrm{cm}^{-3}$. The porosities were $51.6 \%$ and $51.8 \%$ after sintering at $600^{\circ} \mathrm{C}$ and $700^{\circ} \mathrm{C}$. Two-step sintering $\left(1000^{\circ} \mathrm{C} / 1 \mathrm{~h}+\right.$ $1200^{\circ} \mathrm{C} / 1 \mathrm{~h}$ ) resulted in higher microhardness value, which was $724.2 \mathrm{Hv}(7.1 \mathrm{GPa})$. A direct sintering at $1200^{\circ} \mathrm{C} / 1 \mathrm{~h}$ yielded $583.8 \mathrm{Hv}(5.73 \mathrm{GPa})$. The fracture toughness values were $0.56 \mathrm{MPa} \mathrm{m} \mathrm{m}^{1 / 2}$ and $0.623 \mathrm{MPa} \mathrm{m}{ }^{1 / 2}$ for $1200^{\circ} \mathrm{C}$ and $1000^{\circ} \mathrm{C}$ plus $1200^{\circ} \mathrm{C}$, respectively.

\section{References}

[1] J.F. Chen, Z.G. Shen, F.T. Liu, X.L. Liu, J. Yun, Scr. Mater. 49, 509 (2003).

[2] A.K. Nath, C. Jiten, K.C. Singh, Physica B, Condens. Matter 405, 430 (2010)

[3] J.G. Kim, J.G. Ha, T.W. Lim, K. Park, Mater. Lett. 60, 1505 (2006)

[4] W. Chaisan, R. Yimnirun, S. Ananta, Ceram. Int. 35, 173 (2009) 
[5] M.M. Vijatović Petrović, J.D. Bobić, A.M. Radojković, J. Banys, B.D. Stojanović, in: Advances and Applications in Electroceramics II: Ceramic Transactions, Vol. 235. John Wiley 2012, p. 161.

[6] T. Sundararajan, S. Balasivanandha Prabu, S. Manisha Vidyavathy, Mater. Res. Bull. in press.

[7] K.C. Singh, A.K. Nath, Mater. Lett. 65, 970 (2011).

[8] B.D. Stojanovic, A.Z. Simoes, C.O. Paiva-Santos, C. Jovalekic, V.V. Mitic, J.A. Varela, J. Europ. Ceram. Soc. 25, 1985 (2005)

[9] E. Brzozowski, M.S. Castro, J. Europ. Ceram. Soc. 20, 2347 (2000)

[10] S. Ohara, A. Kondo, H. Shimoda, K. Sato, H. Abe, M. Naito, Mater. Lett. 62, 2957 (2008)
[11] S. Panteny, C.R. Bowen, R. Stevens, J. Mater. Sci. 41, 3837 (2006)

[12] O. Namsar, A. Watcharapasorn, S. Jiansirisomboon, J. Microsc. Soc. Thai. 4, 24 (2011).

[13] S. Jiansirisomboon, A. Watcharapasorn, T. Tunkasiri, Chiang Mai J. Sci. 33, 175 (2006)

[14] R.F. Cook, C.J. Fairbanks, B.R. Lawn, Y.W. Mai, J. Mater. Res. 2, (1987)

[15] A.A. Wereszczak, L. Riester, K. Breder, Soc. Automot. Eng. Inc. Techn. Papers 2000-01-1535, 1 (2000) 